Syntax Literate: Jurnal Ilmiah Indonesia p-ISSN: 2541-0849

e-ISSN: 2548-1398

Vol. 5, No. 7, Juli 2020

\title{
DETERMINAN KEBIJAKAN DIVIDEN
}

\section{Lailah Nurjanah dan Negina Kencono Putri}

Fakultas Ekonomi dan Bisnis Universitas Jenderal Soedirman Purwokerto

Email: nurjannah.laila9@gmail.com dan negina.putri@unsoed.ac.id

\section{Abstract}

This research aims to analyze and obtain empirical evidence about the effects of liquidity which is proxied by the current ratio and leverage proxied by debt to equity ratio to the dividend policy proxied by a dividend payout ratio on food and beverage companies listed on the Indonesia Stock Exchange (BEI) for the 20162018 period. Data obtained from the Indonesia Stock Exchange (IDX) webpage. The population in the study was 24 companies. The sampling technique used purposive sampling method, and 9 research samples were obtained. The analytical tool used is the SPSS program version 26. The results of partial testing indicate that there is a positive and significant influence between the current ratio variable on the dividend payout ratio. Then the effect is also positive and significant from the partial test shown between the debt to equity ratio to the dividend payout ratio. Simultaneous test results show that together the two independent variables namely the current ratio and debt to equity ratio have a significant effect on the dividend payout ratio.

Keywords: Current Ratio; Debt to Equity Ratio; Dividend Payout Ratio.

\begin{abstract}
Abstrak
Penelitian ini bertujuan untuk memperoleh bukti empiris tentang pengaruh likuditas yang diproksikan dengan current ratio dan leverage diproksikan dengan debt to equity ratio terhadap kebijakan dividen diproksikan dengan dividend payout ratio pada perusahaan makanan dan minuman yang terdaftar di Bursa Efek Indonesia (BEI) periode 2016-2018. Data diperoleh dari laman web Bursa Efek Indonesia (BEI). Populasi dalam penelitian adalah 24 perusahaan. Teknik pengambilan sampel menggunakan metode purposive sampling, dan diperoleh 9 sampel penelitian. Alat analisis yang digunakan adalah program SPSS versi 26. Hasil pengujian secara parsial menunjukkan bahwa terdapat pengaruh positif dan signifikan antara variabel current ratio terhadap dividend payout ratio. Kemudian pengaruh yang juga positif dan signifikan dari pengujian secara parsial ditunjukkan antara debt to equity ratio terhadap dividend payout ratio. Hasil pengujian secara simultan menunjukkan bahwa secara bersama-sama kedua variabel independen yaitu current ratio dan debt to equity ratio memiliki pengaruh yang signifikan terhadap dividend payout ratio.
\end{abstract}

Kata kunci: Current Ratio; Debt to Equity Ratio; Dividend Payout Ratio. 


\section{Pendahuluan}

Otoritas Jasa Keuangan (OJK) mencatat, pada 2016, pasar modal Indonesia berhasil mencetak rekor tertinggi untuk kapitalisasi pasar maupun frekuensi transaksi tertinggi sepanjang masa. Keadaan pasar modal di Indonesia hingga saat ini dinilai menunjukkan tren yang positif. Kepala Eksekutif Pengawas Pasar Modal OJK Nurhaida mengatakan bahwa kapitalisasi pasar Bursa Efek Indonesia (BEI) per tanggal 30 September 2016 adalah sebesar Rp 5.799 triliun (Sari, 2016). Kondisi pasar modal Indonesia pun tumbuh secara signifikan dari sisi nilai kapitalisasi dengan tren dari posisi Rp 2,73 miliar pada tahun 1977 menjadi Rp 6.870,7 triliun per 8 Agustus 2018, dan hingga pertengahan 2018, BEI pun terus mencatat pencapaian yang melampaui dari tahun sebelumnya, peraihan tersebut dari 31 pencatatan saham baru hingga 7 Agustus 2018 yang mencapai posisi Rp 12 triliun. Bahkan frekuensi perdagangan saham harian pun terus meningkat hingga mencapai 392 ribu kali dan merupakan tertinggi di ASEAN yang didukung oleh aktivitas investor yang mencapai nilai tertinggi hingga 43 ribu investor per hari (Melani, 2018).

Laporan Otoritas Jasa Keuangan (OJK) menunjukkan informasi dari kinerja pasar modal Indonesia pada tahun 2018 yang sangat dipengaruhi oleh kondisi dari stabilitas perekonomian domestik juga pengaruh ekonomi global. Pasar modal sebagai fasilitator dan regulator pun menjadi media yang sangat efektif dalam menyalurkan atau menginvestasikan dana yang mempunyai nilai tambah tersendiri, khususnya dunia usaha dan masyarakat pada umumnya. Bahkan dampak yang dirasakan dengan masuknya perusahaan ke pasar modal dapat meningkatkan tata kelola perusahaan dan meningkatkan reputasi perusahaan. Seiring dengan berkembangnya pasar modal Indonesia, banyaknya sektor industri yang masuk ke dalamnya pun semakin beragam. Salah satu sektor tersebut adalah sektor industri makanan dan minuman. Industri makanan dan minuman merupakan salah satu sektor andalan yang menopang pertumbuhan manufaktur dan juga ekonomi Indonesia. Kementerian Perindustrian mencatat bahwa kontribusi dari industri makanan dan minuman terhadap PDB nasional adalah sebesar 6,21 persen pada triwulan III tahun 2017, dan naik 3,85 persen dibandingkan dengan periode yang sama tahun sebelumnya (Kompas, 2018). Nilai ekspor dari industri makanan tumbuh $11,71 \%$, industri minuman tumbuh 3,16\% pada tahun 2018, serta dalam hal penyerapan tenaga kerja pun telah menyerap 1,2 juta orang (Rihanto, 2019). Sektor industri makanan dan minuman di Indonesia memiliki potensi pertumbuhan yang besar, kita semua tahu bahwa alam Indonesia sangatlah kaya, hal ini mendukung potensi pertumbuhan tersebut ditambah lagi permintaan domestik yang juga besar.

Ini menjadi satu alasan terbukanya prospek yang menguntungkan bagi masyarakat untuk berinvestasi pada perusahaan-perusahaan yang dinilai dapat memberikan keuntungan atau memiliki nilai yang baik dari sisi tingkat pengembalian investasi. Bentuk dari pengembalian investasi tersebut berupa dividend yield (pendapatan dividen) atau capital gain (selisih harga jual saham terhadap harga belinya). Umumnya, investor menginginkan tingkat pengembalian investasi yang relatif 
stabil. Tentu dalam aktivitas investasi ini investor dihadapkan pada berbagai macam risiko. Untuk dapat mengurangi kemungkinan atas risiko yang akan terjadi, investor perlu berbagai informasi lain yang relevan di antaranya keadaan ekonomi dan politik juga informasi yang lazimnya diperoleh dengan didasari pada laporan keuangan perusahaan.

Mengingat begitu pentingnya kebijakan dividen yang harus ditetapkan oleh suatu perusahaan, maka diperlukan adanya pertimbangan faktor-faktor yang mempengaruhinya oleh pihak manajemen perusahaan tersebut. beberapa faktor yang diprediksi mempengaruhi kebijakan dividen adalah likuiditas dan leverage. Likuiditas suatu perusahaan merupakan faktor penting yang perlu dipertimbangkan sebelum mengambil keputusan untuk menetapkan besarnya dividen yang akan dibayarkan kepada para pemegang saham (Rakhmawati, 2017). Kenaikan current ratio menandakan bahwa meningkatnya kas perusahaan, sementara perusahaan yang memiliki likuiditas yang tinggi memiliki kemungkinan memperoleh laba yang kecil dikarenakan kas perusahaan tidak digunakan untuk diputarkan sehingga laba yang didapat oleh perusahaan lebih sedikit dan dampaknya pembayaran dividen bagi investor pun mengalami penurunan (Ano, Murni, \& Van Rate, 2014). Leverage merupakan rasio yang menggambarkan perbandingan antara total utang terhadap ekuitas (Samsul, 2015). Rasio ini juga dapat memberikan informasi untuk mengetahui jumlah dana yang disediakan peminjam (kreditor) dengan pemilik perusahaan (Kasmir, 2012). Selain itu, rasio ini pun dapat memberikan petunjuk umum tentang bagaimana kelayakan dan risiko keuangan dari suatu perusahaan.

Berdasarkan uraian yang dipaparkan di atas peneliti ingin berusaha mengembangkan penelitian lebih lanjut mengenai pengaruh likuiditas yang diproksikan dengan current ratio dan leverage diproksikan dengan debt to equity ratio terhadap kebijakan dividen yang diproksikan dengan dividend payout ratio dengan objek penelitiannya adalah adalah industri makanan dan minuman sebagai bahan penelitian ini dengan judul: "Pengaruh Current Ratio dan Debt to Equity Ratio terhadap Dividend Payout Ratio pada Perusahaan Makanan dan Minuman yang Terdaftar di Bursa Efek Indonesia Periode 2016-2018”.

\section{Metode Penelitian}

Penelitian ini menggunakan metode kuantitatif dengan jenis data yang digunakan adalah data sekunder berupa data laporan keuangan yang diperoleh dengan mengakses laman web Bursa Efek Indonesia (BEI, n.d.) dan laporan statistik (BEI, n.d.b). Populasi penelitian ini adalah perusahaan yang terdaftar di Bursa Efek Indonesia dalam sektor industri makanan dan minuman dengan periode penelitiannya adalah 2016-2018. Data menunjukkan bahwa jumlah perusahaan di sektor industri makanan dan minuman yang terdaftar selama periode 2016-2018 sejumlah 24 perusahaan.

Pemilihan sampel diseleksi dengan teknik purposive sampling. Kriteria yang ditentukan yaitu perusahaan yang konsisten terdaftar di BEI selama periode 2016-2018, perusahaan yang menerbitkan dan mempublikasikan laporan keuangannya secara rutin 
sesuai dengan periode penelitian, perusahaan yang konsisten membagikan dividen selama periode penelitian, perusahaan yang menyajikan laporan keuangan dalam mata uang rupiah dan yang menyampaikan datanya secara lengkap sesuai dengan informasi yang diperlukan selama periode penelitian. Berdasarkan atas populasi dan teknik sampling yang dilakukan diperoleh sampel sejumlah 9 perusahaan yang memenuhi kriteria.

\section{Hasil dan Pembahasan}

\section{A. Hasil}

Berikut adalah hasil pengujian yang dilakukan menggunakan software SPSS versi 26 (Santoso, 2016).

\section{Statistik Deskriptif}

Tabel 1 Analisis Statistik Deskriptif Descriptive Statistics

\begin{tabular}{lrrrrr}
\hline & N & Min & Max & Mean & Std. Deviation \\
\hline CR & 27 &, 64 & 8,64 & 2,8819 & 2,12336 \\
DER & 27 &, 17 & 2,12 &, 7778 &, 50059 \\
DPR & 27 &, 11 & 1,00 &, 4278 &, 26339 \\
Valid N (listwise) & 27 & & & & \\
\hline
\end{tabular}

Sumber: Ouput SPSS 26

\section{Uji Normalitas}

Tabel 2 Uji Normalitas

One-Sample Kolmogorov-Smirnov Test

\begin{tabular}{lr}
\hline \multicolumn{1}{c}{ Unstandardized Residual } \\
\hline Asymp. Sig. (2-tailed) &, $200^{\mathrm{c}, \mathrm{d}}$ \\
\hline Sumber: Ouput SPSS 26
\end{tabular}

Tabel 2 dapat dilihat bahwa nilai uji Kolmogorov-Smirnov menunjukkan angka signifikan sebesar 0,200, hal ini memberikan informasi bahwa data penelitian terdistribusi normal.

\section{Uji Multikolinieritas}

Tabel 3 Uji Multikolinearitas Coefficients $^{\mathrm{a}}$

\begin{tabular}{llrr}
\hline & & \multicolumn{2}{c}{ Collinearity Statistics } \\
\cline { 3 - 4 } Model & & Tolerance & VIF \\
\hline 1 & (Constant) & & \\
& CR &, 469 & 2,132 \\
& DER &, 469 & 2,132 \\
\hline
\end{tabular}

Sumber: Ouput SPSS 26 
Berdasarkan hasil dari tabel 3 menunjukkan bahwa secara keseluruhan semua variabel independen memiliki nilai tolerance di atas 0,10 dan nilai VIF kurang dari 10. Sehingga secara keseluruhan data-data penelitian tidak mempunyai persoalan multikolinearitas.

\section{Uji Heteroskedastisitas}

\section{Gambar 1 Uji Heteroskedastisitas}

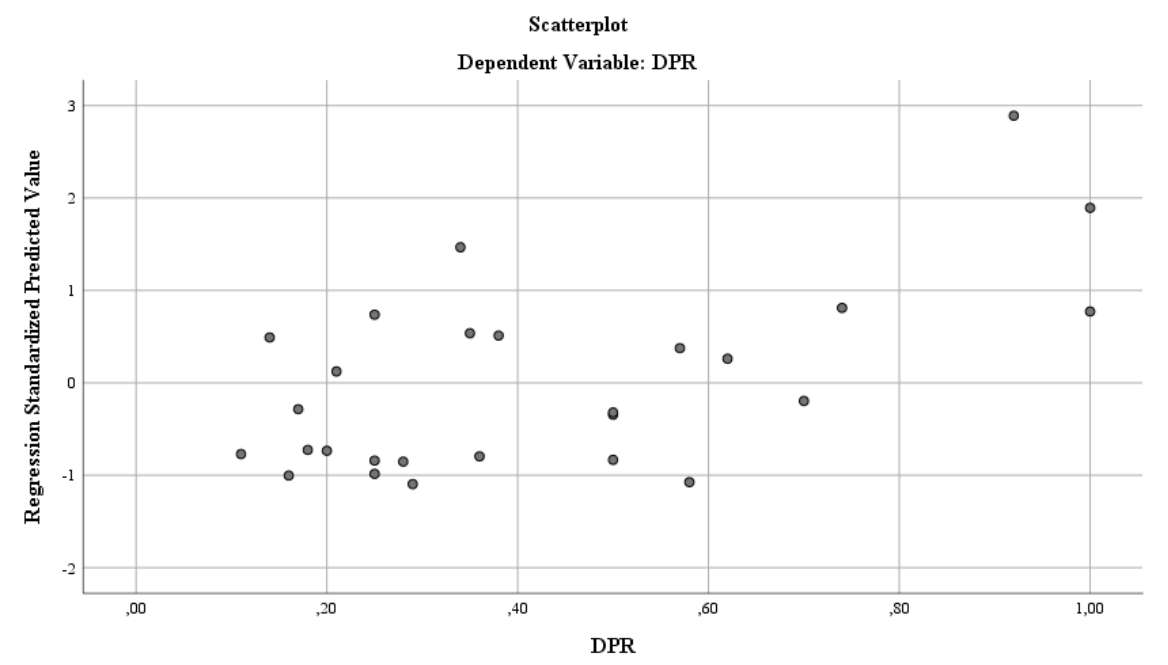

\section{Sumber: Ouput SPSS 26}

Berdasarkan output Scatterplots di atas diketahui bahwa titik-titik menyebar di atas dan di bawah atau di sekitar angka 0, tidak mengumpul dan juga tidak membentuk suatu pola bergelombang. Dengan demikian bahwa tidak terjadi masalah heteroskedastisitas hingga model regresi yang baik serta ideal dapat terpenuhi.

\section{Uji Autokorelasi}

\section{Tabel 4 Uji Run Test}

Runs Test

\begin{tabular}{lr}
\hline & Unstandardized Residual \\
\hline Asymp. Sig. (2-tailed) &, 241 \\
\hline
\end{tabular}

Sumber: Ouput SPSS 26

Berdasarkan hasil run test dapat dilihat bahwa nilai Asymp. Sig. (2tailed) sebesar 0,241 dimana berada di atas 0,05. Hal tersebut menunjukkan bahwa tidak terdapat autokorelasi antar variabel independen pada model regresi penelitian ini. 


\section{Uji Hipotesis}

Tabel 5 Uji Statistik t

Coefficients $^{\mathrm{a}}$

\begin{tabular}{|c|c|c|c|}
\hline Model & & $\mathrm{t}$ & Sig. \\
\hline \multirow[t]{3}{*}{1} & (Constant) &,- 725 &, 476 \\
\hline & $\mathrm{CR}$ & 2,357 &, 027 \\
\hline & DER & 3,606 & ,001 \\
\hline
\end{tabular}

Sumber: Ouput SPSS 26

Berdasarkan tabel di atas dapat dilihat bahwa hasil nilai secara parsial menunjukkan bahwa current ratio berpengaruh positif terhadap dividend payout ratio dengan tingkat signifikansi sebesar 0,027. Hasil nilai secara parsial bahwa dividend payout ratio berpengaruh positif dengan tingkat signifikansi 0,001 .

Tabel 6 Uji Statistik F

\begin{tabular}{|c|c|c|c|}
\hline \multicolumn{4}{|c|}{ ANOVA $^{a}$} \\
\hline Model & & $\mathrm{F}$ & Sig. \\
\hline 1 & Regression & 6,581 &, $005^{\mathrm{b}}$ \\
\hline & Residual & & \\
\hline & Total & & \\
\hline
\end{tabular}

Sumber: Ouput SPSS 26

Berdasarkan hasil uji hipotesis secara silmultan menunjukkan bahwa hasil $F$ hitung sebesar 6,581 dengan nilai signifikansi $0,005 \leq 0,05$. Sehingga dapat ditarik kesimpulan bahwa variabel independen yaitu current rato dan debt to equity ratio secara simultan berpengaruh terhadap dividend payout ratio.

\section{B. Pembahasan}

\section{Pengaruh Current Ratio Terhadap Dividend Payout Ratio}

Berdasarkan dari uji hipotesis yang telah dilakukan menunjukkan bahwa ada pengaruh yang positif dan signifikan antara current ratio terhadap dividend payout ratio. Likuiditas suatu perusahaan menjadi suatu pertimbangan dalam penentuan kebijakan dividen. Tingkat likuiditas perusahaan yang tinggi dapat memberikan gambaran kepada investor bahwa perusahaan mempunyai kemampuan dalam memenuhi kewajiban jangka pendeknya. Likuiditas ini pun dapat menjadi suatu tool bagi manajemen untuk memperbaiki kinerja dan juga menganalisa rencana kinerja ke depan dengan melihat rasio likuiditas tersebut. Hal ini sejalan dengan penelitian yang dilakukan oleh (Ogilo, 2016) yang menyatakan bahwa terdapat hubungan yang positif antara current ratio terhadap 
dividend payout ratio. Ini pun sejalan dengan penelitian yang dilakukan oleh (Zahidda, 2017) dimana terdapat pengaruh antara current ratio terhadap dividend payout ratio, besar kecilnya likuiditas perusahaan akan berdampak pada besar kecilnya dividen yang akan dibagikan, semakin besar kemampuan suatu perusahaan melunasi hutang-hutangnya, khususnya hutang yang jatuh tempo maka akan semakin besar nilai dividen yang akan diberikan dan begitu pun sebaliknya.

\section{Pengaruh Debt to Equity Ratio Terhadap Dividend Payout Ratio}

Berdasarkan uji hipotesis yang telah dilakukan menunjukkan bahwa ada pengaruh positif dan signifikan antara debt to equity ratio terhadap dividend payout ratio. Leverage memberikan petunjuk mengenai proporsi atas penggunaan hutang dalam membiayai investasinya. Peningkatan atas hutang dinilai akan mempengaruhi besar kecilnya laba bersih yang tersedia untuk para pemegang saham. Hal ini didukung oleh hasil penelitian oleh (Sampurno, 2013) yang menyatakan bahwa terdapat pengaruh yang positif dan signifikan antara debt to equity ratio terhadap dividend payout ratio. Menurut (Prihantoro, 2013) menyatakan bahwa debt to equity ratio mencerminkan bagaimana kemampuan perusahaan dalam memenuhi seluruh kewajibannya yang ditunjukkan dengan berapa bagian modal sendiri yang digunakan untuk membayar hutang. Oleh karenanya semakin rendah debt to equity ratio akan semakin tinggi kemampuan perusahaan untuk dapat membayar semua kewajibannya.

\section{Pengaruh Current Ratio dan Debt To Equity Ratio Terhadap Dividend Payout Ratio}

Berdasarkan hasil uji hipotesis yang telah dilakukan, hubungan pengaruh antara current ratio dan debt to equity ratio menunjukkan adanya pengaruh yang signifikan dari kedua variabel tersebut terhadap dividend payout ratio. Hal ini diharapkan menjadi suatu bahan pertimbangan bagi investor maupun manajemen perusahaan dalam menetapkan kebijakan dividen yang akan dilakukan, dan juga menjadi bahan evaluasi untuk membuat strategi yang lebih baik.

\section{Kesimpulan}

Berdasarkan hasil analisis dan penelitian secara parsial yang telah dilakukan dengan objek penelitian perusahaan industri makanan dan minuman yang terdaftar di Bursa Efek Indonesia (BEI) periode 2016-2018 bahwa current ratio dan debt to equity ratio memiliki pengaruh yang positif dan signifikan terhadap dividend payout ratio. Kemudian secara simultan dari penelitian ini diketahui bahwa variabel independen yaitu current ratio dan debt to equity ratio secara bersama-sama memiliki pengaruh yang signifikan terhadap dividend payout ratio. 


\section{BIBLIOGRAFI}

Ano, Rizky Rurniawan, Murni, Sri, \& Van Rate, Paulina. (2014). Pengaruh Likuiditas Dan Profitabilitas Terhadap Devidend Payout Ratio Pada Subsektor Perbankan Yang Terdaftar Di Bursa Efek Indonesia Periode 2009-2013. Jurnal EMBA: Jurnal Riset Ekonomi, Manajemen, Bisnis Dan Akuntansi, 2(3).

Indonesia, Bursa Efek. (n.d.-a). Laporan Keuangan dan Tahunan. Retrieved June 22, 2020, from https://www.idx.co.id/perusahaan-tercatat/laporan-keuangan-dantahunan/

Indonesia, Bursa Efek. (n.d.-b). Laporan Statistik.

Kasmir. (2012). Analisis Laporan Keuangan. Jakarta: Rajawali Pers.

Kompas. (2018). Cerah, Masa Depan Industri Makanan dan Minuman di Indonesia. Retrieved June 22, 2020, from https://ekonomi.kompas.com/read/2018/09/27/150000226/cerah-masa-depanindustri makanan-dan-minuman-di-indonesia

Melani, Agustina. (2018). Melihat Perkembangan Pasar Modal RI Selama 41 Tahun. Retrieved June 25, 2020, from Liputan 6 website: https://www.liputan6.com/bisnis/read/3615885/melihat-perkembangan-pasarmodal-ri-selama-41-tahun

Ogilo, F. (2016). Determinants of Dividends Pay-out Ratio for Listed Commercial Banks in Kenya 2016. Jhe International Journal of Business \& Management, 4, 469-473.

Prihantoro. (2013). Estimasi Pengaruh Dividend Payout Ratio pada Perusahaan Publik di Indonesia. Jurnal Akuntansi Dan Keuangan. Retrieved from http://www.jurnalakuntansidankeuangan.com

Rakhmawati, Annisa Desi. (2017). Pengaruh Current Ratio (Cr), Leverage, Return On Assets (ROA) Dan Growth Terhadap Dividend Payout Ratio (DPR) Pada Perusahaan Manufaktur Yang Listing Di Bursa Efek Indonesia Periode 2008-2012. Jurnal Profita: Kajian Ilmu Akuntansi, 5(5).

Rihanto, Dodo. (2019). Pertumbuhan Industri Makanan dan Minuman Sumbang 6,35\% terhadap PDB Nasional. Retrieved June 25, 2020, from Pikiran Rakyat website: https://www.pikiran-rakyat.com/ekonomi/pr-01316389/pertumbuhan-industrimakanan-dan-minuman-sumbang-635-terhadap-pdb-nasional.

Sampurno, Unzu Marietta dan Djoko. (2013). Analisis Pengaruh Cash Ratio, Return on Assets, Growth, Firm Size, Debt to Equity Ratio Terhadap Dividend Payout Ratio : (Studi Pada Perusahaan Manufaktur Yang Terdaftar di Bursa Efek Indonesia Tahun 2008-2011). Diponegoro Journal of Management, 2(3), 1-11. Retrieved from http://ejournal-s1.undip.ac.id/index.php/dbr. 
Lailah Nurjanah dan Negina Kencono Putri

Samsul, Mohamad. (2015). Pasar Modal dan Manajemen Portofolio Edisi 2. Erlangga. Jakarta.

Santoso, Singgih. (2016). Panduan Lengkap SPSS Versi 26. Elex Media Komputindo.

Sari, Novita Intan. (2016). Di 2016, pasar modal Indonesia cetak sejumlah rekor. Retrieved from Merdeka website: https://www.merdeka.com/uang/di-2016-pasarmodal-indonesia-cetak-sejumlah-rekor.html

Zahidda, Dewi. (2017). Pengaruh Profitabilitas, Likuiditas, Posisi Kas Terhadap Kebijakan Dividen pada Perusahaan Food Beverages. Jurnal Ilmu Dan Riset Manajemen (JIRM), 6(2). 